\title{
Hospital Histories in the College Library
}

Members may be interested to know that the College Library holds a small collection of histories of individual hospitals. They range from short, privately produced pamphlets to comprehensive studies and cover a variety of institutions, some long since closed. As most of these works are now out of print (many were originally produced in limited numbers), members may care to consult them in the Library. In some cases duplicate copies are available for loan.

It is hoped to add to this collection and I should be very pleased to know of any other hospital histories available.

Susan Floate

Librarian

\section{BETHEL HOSPITAL}

Bateman, F. \& RYE, W. The History of Bethel Hospital. Norwich: Gibbs. 1906. Pp 251. Illus.

BETHLEM HOSPITAL

O'Donoghue, E. G. The Story of Bethlehem Hospital from its Foundation in 1247. London: Unwin. 1914. Pp 427. Illus.

BRENTRY HOSPITAL

JANCAR, J. Fifty years of Brentry Hospital (1922-1972). Reprinted from the Bristol Medico-Chirurgical Journal, Vol. 87 (iii), No. 323, July 1972. Pp 7. Illus.

BRIDEWELL HOSPITAL

O'Donoghue, E. G. Bridewell Hospital: Palace, Prison, Schools. London: Bodley Head. 1923. Pp 262. Illus.

CEFN COED HOSPITAL

DAvies, T. G. A History of Cefn Coed Hospital. Industrial Therapy Department, West Glamorgan Health Authority. 1982. Pp 38. Illus.

CHEADLE ROYAL HOSPITAL

BrockBANK, E. M. A Short History of Cheadle Royal. Manchester: Sherratt. 1934. Pp 76. Illus.

Roberts, N. Cheadle Royal Hospital-a Bicentenary History. Altrincham: Sherratt. 1967. Pp 189. Illus.

CITY OF LONDON ASYLUM

WHITE, J.G. A Short Account of the City of London Asylum. London: The Corporation. 1901. Pp 28. Illus.

CRAIG DUNAIN HOSPITAL

Whrtret, M. M. Craig Dunain Hospital, Inverness: One Hundred Years, 1864-1964. Inverness. 1964. Pp 90. Illus.

CRICHTON ROYAL HOSPITAL

EAsterbrook, C.C. The Chronicle of Crichton Royal (1833-1936). Dumfries: Courier. 1940. Pp 663. Illus.

TURner, G. B. The Chronicle of Crichton Royal, 1937-1971. Carlisle: Cumbrian Newspapers. 1980. Pp 282. Illus.

EAST RIDING ASYLUMS

Bickrord, J. A. R. \& Bickford, M. E. The Private Lunatic
Asylums of the East Riding. Beverley: East Yorks Local History Society. 1976. Pp 58.

EXE VALE HOSPITAL

IRvine, E. D. Exe Vale Hospital, 1948-1974. Exeter: Devon AHA. 1976. Pp 106. Illus.

FISHPONDS ASYLUM

PHILlips, H.T. The History of the Old Private Lunatic Asylum at Fishponds, Bristol, 1740-1859. University of Bristol. 1973. (MSC thesis). Pp 333. Illus.

FRIERN HOSPITAL

Hunter, R. \& MACAlPINe, I. Psychiatry for the Poor: 1851 Colney Hatch Asylum-Friern Hospital 1973. Chatham: W \& J Mackay. 1974. Pp 264. Illus.

GARLANDS HOSPITAL

PrTT, J. P. A History of Garlands Hospital: The First Ten Years. No date given. Pp 15.

HATTON HOSPITAL

Spratley, V. A. \& Stern, E. S. History of the Mental Hospital at Hatton in the County of Warwick. Hatton Hospital. 1952? Pp 26. Illus.

HORTON WAR HOSPITAL

LORD, J. R. The Story of the Horton (Co. of London) War Hospital, Epsom: Its Inception and Work and Some Reflections. London: Heinemann. 1920. Pp 264. Illus.

HORTON ROAD HOSPITAL

BAlLeY, A. An Account of the Founding of the First Gloucestershire County Asylum, now Horton Road Hospital, Gloucester, 1793-1823. Pp 13.

HOXTON MADHOUSES

MORRIS, A.D. The Hoxton Madhouses. Cambridge: Goodwin. 1958. Pp 49.

HULL BOROUGH ASYLUM

Bickpord, J.A. R. The Old Hull Borough Asylum (1849-1883). Hull: City Records Office. 1981. Pp 52.

\section{LACHLAN PARK HOSPITAL}

Crabbe, G. M. History of Lachlan Park Hospital. Hobart(?): Wilkinson, 1966(?) Pp 59. Plan.

LAWN HOSPITAL

SHEFPIELd REgional Hospital BoARd \& Lincoln Health Hospital management Committee. A Booklet to Mark the One Hundred and Fiftieth Anniversary of the Lawn Hospital, Lincoln. 1970? Pp 22. Illus.

MeLton, B. L. One Hundred and Fifty Years at the Lawn. No date given. Pp 26.

MAGDALEN HOSPITAL

PEARCE, S.'B. P. An Ideal in the Working: The Story of Magdalen Hospital, 1758 to 1958. London: Skinner. 1958. Pp 100. Illus.

MANCHESTER ROYAL INFIRMARY HOSPITAL

BroCKBANK, E. M. The Manchester Royal Infirmary and Royal Mental Hospital. Reprinted from The Medical 
Press and Circular, Vol CCIII, No 5252, July 1940. Pp 19. Illus.

Renaud, F. A Short History of the Rise and Progress of the Manchester Royal Infirmary from the year 1752 to 1877. Manchester: Cornish. 1898. Pp 152.

MAPPERLEY HOSPITAL

MAPPERLEY HospITAL Nottingham, The Hospital: 1880-1980. Pp 38. Illus.

MEANWOOD PARK HOSPITAL

SPENCER, D. A. The History and Modern Development of Meanwood Park Hospital, Leeds, 1920-1974. 1974. Pp 19.

Spencer, D. A. The History of Meanwood Park Hospital, Leeds. (Sixtieth Anniversary Year 1979-80). Leeds: The Hospital. 1980. Pp 29.

Spencer, D. A. Meanwood Park Hospital, Leeds-A History. Leeds: The Hospital. 1982. Pp 39.

MIDDLEWOOD PSYCHIATRIC HOSPITAL

THORPE, F. T. A History of Middlewood Psychiatric Hospital. The Hospital. 1972? Pp 60. Illus.

MONTROSE ROYAL ASYLUM

Montrose Royal Asylum for the Insane, 1781-1900. Edinburgh: Riverside. Pp 26.

MOORHAVEN HOSPITAL

Pilkington, F. Moorhaven Hospital, Ivybridge, South Devon: Historical Review 1891-1953. The Hospital. 1953? Pp 18.

Pilkington, F. Moorhaven Hospital, Ivybridge, South Devon: Historical Review 1891-1958. 2nd ed. The Hospital. 1958? Pp 24.

MORGANNWG HOSPITAL

Morgannwg Hospital, Bridgend Centenary Brochure 1864-1964. Bridgend: The Hospital. 1964? Pp 28. Illus.

MURRAY ROYAL HOSPITAL

Chambers, W. D. et al. The History of Murray Royal Hospital 1827-1977. No date given. Pp 36. Illus.

OAKWOOD HOSPITAL

Kent County Library. A History of Oakwood Hospital, 1828-1982. Kent County Council. 1983. Pp 22. Illus.

\section{OLD MANOR HOSPITAL}

SMTth, G. The Old Manor Hospital. 1978? Pp 74. Illus.

THE RETREAT

TUKE, D. H. Reform in the Treatment of Insanity: Early History of The Retreat, York: Its Objects and Influence, with a Report of the Celebrations of its Centenary. London: Churchill. 1892. Pp 96. Illus.

HuNT, H.C. A Retired Habitation-A History of the Retreat, York. London: Lewis, 1932. Pp 144. Illus.

ROYAL EDINBURGH HOSPITAL

Focus on Change-The Royal Edinburgh Hospital 1955-1965. Edinburgh. 1965? Pp 56. Illus.

\section{RUNWELL HOSPITAL}

Opening of Runwell Hospital by the Right Hon Sir Kingsley Wood, 14th June, 1937. East Ham and Southend-onsea Joint Visiting Committee. 1937? Pp 24. Illus.

ST ANDREW'S HOSPITAL

St Andrew's Hospital, Northampton. Press Information. 1981. Pp 9.

ST CRISPIN HOSPITAL

AYRES, H. A Changing Community: The Brief History of St Crispin Hospital, Duston, Northampton 1876-1976. Northants AHA. 1976? Pp 47. Illus.

ST LAWRENCE'S HOSPITAL, BODMIN

ANDREWS, C. T. The Dark Awakening: A History of St Lawrence's Hospital, Bodmin. London: Cox. 1978. Pp 276. Illus.

ST LAWRENCE'S HOSPITAL, CATERHAM

Gibson, J. St Lawrence's Hospital, Caterham, Surrey, 1870-1956. The Hospital. 1956? Pp 12. Illus.

ST LUKE'S HOSPITAL

French, C. N. The Story of St Luke's Hospital. London: Heinemann. 1951. Pp 212. Illus.

ST PATRICK'S HOSPITAL

The Legacy of Swifl-A Bicentenary Record of St Patrick's Hospital, Dublin. The Hospital. 1948. Pp 70. Illus.

SIR PATRICK DUN'S HOSPITAL

MOORHEAd, T. G. A Short History of Sir Patrick Dun's Hospital. Dublin: Hodges. 1942. Pp 228. Illus.

STANLEY ROYD HOSPITAL

AsHWORTH, A. L. Stanley Royd Hospital, Wakefield: One Hundred and Fifty Years-a History. The Hospital. 1975. Pp 77. Illus.

STOKE PARK HOSPITAL

JANCAR, J. Research at Stoke Park-Mental handicap (1930-1980). Dorchester: Dorset Press. 1981. Pp 69. Illus.

JanCAR, J. Sixty years of Stoke Park Hospital (1909-1969). Reprinted from the Bristol Medico-Chirurgical Journal, July 1969. Pp 30. Illus.

SUNNYSIDE ROYAL HOSPITAL

Presly, A. S. A Sunnyside Chronicle: A History of Sunnyside Royal Hospital, Produced for its Bi-Centenary. The Hospital. 1981. Pp 57. Illus.

TAVISTOCK CLINIC

Dicks, H. V. 50 Years of the Tavistock Clinic. London: Routledge. 1970. Pp 415. Illus.

WARLEY HOSPITAL

Warley Hospital, Brentwood: The First Hundred Years 1853-1953 Incorporating the Second Century 1953-1963. The Hospital. 1969? Pp 51. Illus.

WARNEFORD HOSPITAL

COMMITTE OF MANAGEMENT Brief History of the Warneford Hospital. The Hospital. 1926. Pp 15. Illus.

The Warneford Hospital, Oxford 1829-1976. The Hospital. 1976. Pp 24. Illus. 